\title{
Site-specific height curves for white spruce (Picea glauca [Moench] Voss) stands based on stem analysis and site classification
}

\author{
GG Wang ${ }^{1}, \mathrm{~K}$ Klinka ${ }^{2}$ \\ 1 Department of Biology, University of Winnipeg, 515 Portage Avenue, \\ Winnipeg, MB, Canada R3B 2E9; \\ 2 Department of Forest Sciences, University of British Columbia, Vancouver, BC, Canada V6T $1 Z 4$
}

(Received 2 January 1994; accepted 15 May 1995)

\begin{abstract}
Summary - Polymorphic height curves have been widely used to predict dominant stand height from site index or any known pair of height and age. To provide an alternative to this conventional approach, height modelling was linked to site classification using stem analysis and site data obtained from 102 naturally established white spruce (Picea glauca [Moench] Voss) stands in the Sub-Boreal Spruce zone of British Columbia. The study stands were stratified according to their soil moisture, aeration and nutrient regimes, and a site-specific height curve was developed for each of the 7 delineated groups without using site index as a predictor. Although less precise, the curves developed were comparable to the conventional height curves that use site index as a predictor. Testing against independent data indicated that the site-specific height curves were reliable and applicable over a large area of the sub-boreal forest for predicting dominant heights of white spruce stands.
\end{abstract}

Picea glauca / height curve / site-specific height curve / site classification

Résumé - Courbe de croissance en hauteur de l'épinette blanche (Picea glauca [Moench] Voss) par l'utilisation de données d'analyse de tige et de typologie des stations. L'utilisation de courbes polymorphes de croissance en hauteur est très courante pour prédire la hauteur dominante d'un peuplement connaissant un indice de fertilité ou un couple hauteur-âge. Nous proposons une alternative à cette méthode en reliant directement un modèle de croissance en hauteur aux conditions de station, par l'utilisation de données d'analyse de tige et de typologie des stations dans 102 placettes de peuplements naturels d'épinette blanche (Picea glauca [Moench] Voss) en région sub-boréale de Colombie britannique. Les peuplements choisis ont été stratifiés selon le régime hydrique du sol, la compacité, la qualité nutritive, et des courbes de croissance spécifiques ont été construites pour chacun des 7 groupes sans utiliser l'indice de fertilité comme paramètre. Bien que moins précises, les courbes obtenues sont comparables aux courbes plus conventionnelles qui utilisent lindice de fertilité comme paramètre. La liaison entre les types de station et les courbes est significative, comme le montre un essai 
où cette hypothèse a été testée comme lindépendance entre les courbes et les types de station. Ce modèle est applicable dans une grande partie de la forêt sub-boréale pour prédire la hauteur dominante des peuplements d'épinette blanche.

Picea glauca / courbe de croissance en hauteur/ courbe de croissance dépendant de la station / typologie des stations

\section{INTRODUCTION}

Forest management for sustained timber production requires accurate information on forest growth and yield. For this purpose, various forest growth and yield models have been developed (eg Clutter et al, 1983; Davis and Johnson, 1987). Traditionally, these models are based on 'historical bioassays' and, therefore, are empirical models. Empirical models have been used over the past several decades, and are essentially the only type used in western North America. As long as the future growth conditions remain similar to the past, the use of these models will continue to be justified (Kimmins, 1985; Kimmins et al, 1990). However, some possible changes in environmental conditions may likely result in a situation in which growth conditions are no longer treated as immutable. Thus, concerns about the validity of empirical models in predicting future growth and yield led to the development of mechanistic models (eg Agren and Axelsson, 1980; Shugart, 1984; Bossel, 1986; Running and Coughlan, 1988). Mechanistic models may be superior to empirical models under a changing environment (Landsberg, 1986; Bossel, 1991), but many authors argue that more effort is needed for existing mechanistic models to match the precision of the empirical models calibrated from forest-wide inventory and growth plot data bases (Leech, 1984; Rayner and Turner, 1990).

Among various types of growth and yield models, height modelling received considerable research attention. Height of domi- nant trees in even-aged stands has been accepted as a measure of forest productivity, and used as a 'driving' variable in many models (Wykoff and Monserud, 1987). Conventional height models require site index as an independent variable for predicting height; site index is, in turn, estimated from site index curves or tables (developed through 'historical bioassay') using a known pair of age and height. Changes in environment (ie changes in the ecological quality of forest sites) would not be accounted for by empirical models unless these environmental variables were explicitly included in the models. Replacing site index in empirical models with site descriptors (ecological variables) has been suggested to accommodate the changes in environment (West, 1990).

Direct incorporation of quantitative environmental variables in height models is presently limited by the resolution (time and spatial scale) and the nature of available climatic and edaphic data (Nautiyal and Cuoto, 1984; Rayner and Turner, 1990). Consequently, alternative site describers, such as those derived from site classification, have received considerable attention (eg Green et al, 1989; Inions, 1990; Inions et al, 1990; Klinka and Carter, 1990).

The primary objective of this study was to establish a link between height modelling and site classification, a part of a larger study carried out by Wang (1993). Considering the usefulness of site classification in delineating ecologically equivalent sites and in addressing relationships between site index and measures of ecological site quality for several tree species of British 
Columbia (eg Green et al, 1989; Klinka and Carter, 1990; Wang et al, 1994), it would seem possible, using the framework of site classification, to develop height models in which site index is replaced by measures of ecological site quality. Study stands were stratified into site groups according to their ecological site quality in supporting white spruce height growth, and site-specific height curves for predicting dominant height were developed for the delineated site groups. To evaluate the performance of the curves, conventional height curves were also developed using stem analysis data. Independent data were then used to test the site-specific curves for their reliability and portability.

\section{MATERIALS AND METHODS}

The study area occupied the central and southern portions of the Sub-Boreal Spruce (SBS) biogeoclimatic zone, extending from approximately $52^{\circ} 30^{\prime}$ to $54^{\circ} 18^{\prime} \mathrm{N}$ latitude and from $122^{\circ} 0^{\prime}$ to $125^{\circ} 54^{\prime} \mathrm{W}$ longitude. Using the maps obtained from the British Columbia Forest Service, 102 stands were located into 6 biogeoclimatic subzones or variants: 1) Horsefly Dry Warm SBS variant (SBSdw1), 2) Stuart Dry Warm SBS vari- ant (SBSdw3), 3) Dry Cool SBS subzone (SBSdk), 4) Moist Warm SBS subzone (SBSmw), 5) Moist Cool SBS subzone (SBSmk) and 6) Wet Cool SBS subzone (SBSwk) (Meidinger and Pojar, 1991). Each biogeoclimatic unit was selected to represent a segment of a regional climatic gradient. Within each unit, study stands were selected to represent the widest possible range of soil moisture and nutrients for white spruce growth (table 1). Only naturally regenerated, fully stocked, unmanaged and even-aged white spruce-dominated stands without a visible history of damage were chosen for the study. In each stand, a $20 \mathrm{x}$ $20 \mathrm{~m}$ (0.04 ha) sample plot was located to represent an individual ecosystem relatively uniform in topography, soil and vegetation characteristics.

The site quality of each study stand was determined by characterizing its soil moisture, aeration and nutrient regimes (SMRs, SARs and SNRs, respectively). Seven SMRs were differentiated according to actual/potential evapotranspiration ratio and the depth to a ground-water table, a gleyed layer or prominent mottling; 3 SARs according to soil water saturation, soil texture and slope and 5 SNRs according to soil mineralizable $\mathrm{N}$ and $\mathrm{C} / \mathrm{N}$ (Wang, 1993). Based on the SMR, SAR and SNR determined for each stand, study stands were stratified into 7 site groups: $C, F, G$, $\mathrm{I}, \mathrm{J}, \mathrm{K}$ and $\mathrm{L}$ as delineated and labelled by Wang (1993). Each site group represents a group of sites with similar soil moisture, aeration and nutrient conditions as well as white spruce site index (fig 1). A more detailed account of SMRs, SARs

Table I. Number, elevation, age and site index (height at 50 years of breast height age [bha]) of the study stands according to biogeoclimatic units.

\begin{tabular}{lcccr}
\hline $\begin{array}{l}\text { Biogeoclimatic } \\
\text { units }\end{array}$ & $\begin{array}{c}\text { No } \\
\text { of plots }\end{array}$ & $\begin{array}{c}\text { Elevation } \\
(m)\end{array}$ & $\begin{array}{c}\text { Age at } b h \\
\text { (year) }\end{array}$ & $\begin{array}{c}\text { Site index } \\
(m)\end{array}$ \\
\hline SBSdw1 & & & & \\
SBSdw3 & 18 & $488-800$ & $43-128$ & $4.7-23.0$ \\
SBSdk & 13 & $746-1006$ & $56-111$ & $11.8-22.6$ \\
SBSmw & 13 & $644-844$ & $47-88$ & $11.9-20.9$ \\
SBSmk & 15 & $788-1008$ & $42-97$ & $12.9-24.2$ \\
SBSwk & 15 & $696-861$ & $48-115$ & $15.5-21.6$ \\
Total & 28 & $766-1026$ & $32-88$ & $7.5-24.1$ \\
& 102 & $488-1026$ & $32-128$ & $4.7-24.2$ \\
\hline
\end{tabular}

\footnotetext{
"SBSdw1: Horsefly Dry Warm SBS variant; SBSdw3: Stuart Dry Warm SBS variant; SBSdk: Dry Cool SBS subzone; SBSmw: Moist Warm SBS subzone; SBSmk: Moist Cool SBS subzone; SBSwk:Wet Cool SBS subzone.
} 


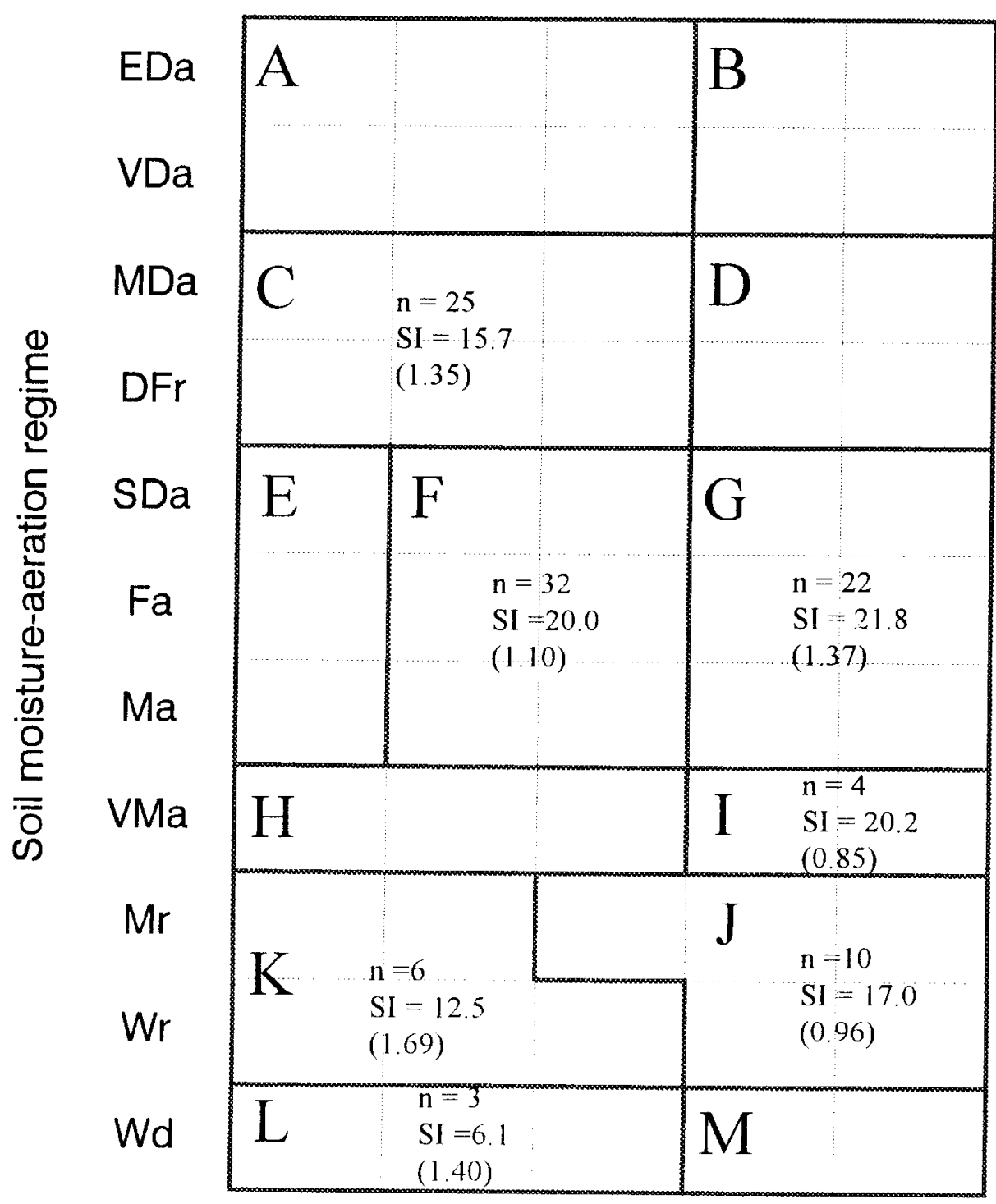

Fig 1. An edaphic grid, defined by soil moisture-aeration regime and soil nutrient regime, showing the site groups delineated by Wang (1993) with number of plots, mean site index $(\mathrm{m})$ and standard deviation ( $m$, in parenthesis). Symbols for soil moisture-aeration regimes (SMARs) are: EDa: exccessively dry and aeration adequate; VDa: very dry and aeration adequate; $\mathrm{MDa}$ : moderately dry and aeration adequate; DFr: moderately dry to fresh and aeration restricted; SDa: slightly dry and aeration adequate; Fa: fresh and aeration adequate; Ma: moist and aeration adequate; VMa: very moist and aeration adequate, Mr: moist to very moist and aeration restricted; Wr: wet and aeration restricted and Wd: wet to very wet and aeration deficient. Symbols for soil nutrient regimes (SNRs) are: VP: very poor; P: poor; M: medium; $R$ : rich and VR: very rich. Significant differences $(\alpha=0.05)$ in site index were observed between any possible pair of site groups except between groups $F$ and $I$ and between $G$ and I. 
and SNRs and site classification is given by Wang (1993).

On each plot, 3 dominant trees, with the largest diameter at breast height, were felled for stem analysis. Their total heights were measured in the field. Stem discs were cut at $0.3,0.6$ and $1.3 \mathrm{~m}$ above the ground surface, and then were taken at $1 \mathrm{~m}$ intervals between $1.3 \mathrm{~m}$ and the top of each tree. On each disc, rings were counted. If necessary, ring counting was assisted by a microscope.

Height/age data obtained from stem analysis can be biased if the height of the cross-cut is taken as the tree height for the given age, because of the presence of a "hidden tip" above the cross-cut (Carmean, 1972). Dyer and Bailey (1987) compared 6 published algorithms for estimating the true height within a section and concluded that Carmean's (1972) method was the best. Therefore, the raw stem analysis data were adjusted using Carmean's (1972) algorithm to calculate tree height corresponding to the age at each cross-cut. Plots of height versus age were examined for each site tree. If growth suppression was apparent, data from that site tree was deleted or truncated. In consequence, 6 trees were deleted, and the remaining 300 site trees were used in further analyses.

An average height growth curve was determined for each plot from the individual tree stem analysis data using Richards' (1959) 3-parameter model:

$$
H=1.3+b_{1}\left(1-e^{-b_{2} \mathcal{A}}\right)^{b_{3}}
$$

where $H$ is height $(\mathrm{m}), A$ is age (years) at breast height, $e$ is the base of the natural logarithm, and $b_{1}, b_{2}$ and $b_{3}$ are parameters to be estimated for each stand.

Within-plot standard errors of estimates for model [1] averaged $0.79 \mathrm{~m}$, with a standard deviation of $0.28 \mathrm{~m}$. The model was evaluated for each stand at every decade from age 10 years to the decadal age nearest the age of the oldest tree in that stand to provide the data base used for constructing height growth curves. All the height-age pairs over 100 years of breast heightage (bha) were excluded from height modelling, as average site index plotted against age showed a significant decline beyond the bha of 100 years. Site index of each stand was determined from the model by setting bha to 50 years. As a result, 672 decadal observations of height, age and site index for 102 stands were produced. Of these,
596 observations from 82 stands with bha greater than 50 years were used to develop height models which required site index as a predictor. For the models without site index, all 672 observations from the 102 stands were used to calibrate the model coefficients.

Site-specific height curves were developed by fitting Richards' model (eq [1]) to the data of each site group. Site index was not used as a predictor, but it was implicitly expressed in the modelling by site group. The effect of ecological site quality on white spruce height growth was indicated by different model coefficients calibrated from data of different site groups. The delineated site-specific curves were compared to conventional height curves in terms of their precision to predict dominant height of white spruce stands. Conventional height curves were developed by fitting a conditioned logistic model (eq [2]) to the data of this study:

$$
H=1.3+(S I-1.3) \frac{1+e^{\left[b_{1}+b_{2} \ln (50)+b_{3} \ln (S / 1.3)\right]}}{1+e^{\left[b_{1}+b_{2} \ln (A)+b_{3} \ln (S /-1.3)\right]}}
$$

where $S /$ is site index ( $\mathrm{m}$ at 50 years of bha); $H$, $A$ and $e$ are as previously defined in eq [1] and $b_{1}$, $b_{2}$ and $b_{3}$ are model coefficients. It was appropriate to select this model for assessing the performance of site-specific height curves as the same model was employed by Goudie and Mitchell (1986) to develop white spruce height curves for interior British Columbia and Alberta.

The applicability of the developed site-specific height curves was evaluated by testing the curves against independent data obtained from Wang et al (1994). As they did not determine soil aeration regime, only the study stands with moderately dry, slightly dry, fresh and moist SMRs (all likely with adequate aeration) were used in the testing.

SYSTAT (Version 5.0) statistical package (Wilkinson, 1990a, b) was applied to statistical analysis and graphics. Derivative-free QuasiNewton methods (Greene, 1990; Wilkinson, $1990 \mathrm{~b})$ were adopted to compute the least squares estimation of the parameters for all the nonlinear regression models. The $R^{2}$ reported for the nonlinear model was the corrected $R^{2}$ (Wilkinson, 1990b), calculated as:

$$
R^{2}=1-\frac{\sum e_{i}^{2}}{\sum\left(y_{i}-\bar{y}\right)^{2}}
$$


where $\bar{y}$ is the mean of the dependent variable and $e_{i}$ and $y_{i}$ are the residual and the measure of the dependent variable for $i^{\text {th }}$ observation, respectively. Although the $R^{2}$ of a nonlinear regression model is no longer guaranteed to be in the range of 0 to 1 , it does provide a useful descriptive measure of the fit of the regression (Greene, 1990).

\section{RESULTS}

The $b$ coefficients, $R^{2}$ and standard error of estimates (SEE) of the developed site-specific curves are given in table II. Coefficient $b_{1}$, which was highly correlated with the mean site index of each site group $(r=0.92)$, represents the average asymptotic value of each site group. As expected, the highest values were found for site groups $G$ and I (sites with sufficient soil water, aeration and nutrients), and the lowest value for site group $L$ (sites with deficient aeration and nutrients). The shape of the average curve for each site group was also different, as indicated by coefficients $b_{2}$ and $b_{3}$ (table II; fig 2). These coefficients represent the average trend of height over age development (ie the average height growth pattern in each site group).

Height curves for site groups $F, G$ and I were very close to each other before age 20 years, but spread afterward. The height curve for the site group $\mathrm{G}$ was consistently above any of the other curves up to 100 years. This suggested that the best growth of white spruce occurs on slightly dry to moist, adequately aerated and rich to very rich sites. Height curves for site groups $F$ and I were nearly identical up to 60 years. After this, the height growth in site group I surpassed that in site group $F$, and approximated the height growth on site group $G$ after 100 years. Height curves for site groups $\mathrm{C}$ and $\mathrm{J}$ intersected twice (approximately at 15 and 70 years). Before the first and after the second intersections, height growth of the stands in site group $C$ was superior to those in site group J. Although it was consistently lower, the height curve for site group $\mathrm{K}$ paralleled that of site group $C$ despite contrasting soil moisture regimes between the site groups (water deficit for site group $\mathrm{C}$ versus water saturation for site group K). Height growth in site group $L$ was the lowest among all the site groups due to deficient aeration caused by a stagnant and high ground water table.

Similar trends among site groups were found when the differential forms of the sitespecific height curves were plotted (fig 3). Until approximately 25 years of bha, the maximum annual height increment decreased in order of site groups: $\mathrm{G}>\mathrm{F}>\mathrm{I}>\mathrm{J}>\mathrm{C}>\mathrm{K}>\mathrm{L}$. After this age, several shifts occurred. For example, the increment of the stands in site group I increased and, surpassed that in other site groups after 60

Table II. Site-specific height models: coefficients, coefficients of determination and standard errors of estimates (SEE) for equation [1] fitted to each of the 7 site groups.

\begin{tabular}{llllll} 
Site group & $b_{1}$ & $b_{2}$ & $b_{3}$ & $R^{2}$ & SEE \\
\hline & & & & & \\
C & 28.65 & 0.02061 & 1.544 & 0.954 & 1.40 \\
F & 30.93 & 0.02560 & 1.559 & 0.975 & 1.09 \\
G & 37.50 & 0.02192 & 1.498 & 0.967 & 1.40 \\
I & 38.63 & 0.01868 & 1.434 & 0.988 & 0.90 \\
J & 22.42 & 0.03795 & 2.206 & 0.965 & 1.18 \\
K & 24.66 & 0.02223 & 1.921 & 0.938 & 1.17 \\
L & 10.70 & 0.01984 & 1.680 & 0.886 & 0.93
\end{tabular}




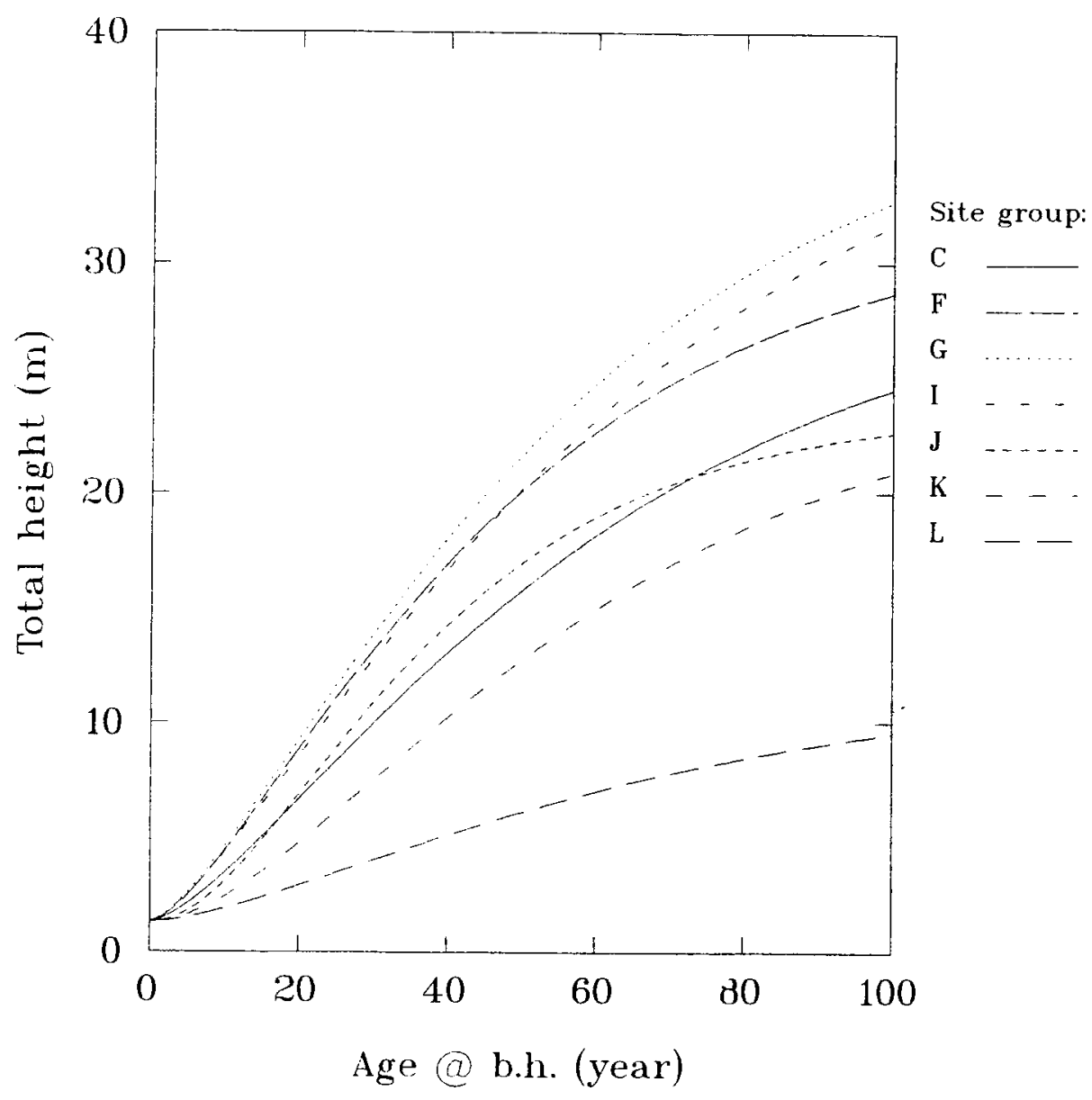

Fig 2. White spruce height curves for each of the 7 site groups obtained from the site-specific models specified in table II.

years. Similarly, after about 50 and 70 years, the increment of the stands in site groups $\mathrm{C}$ and $\mathrm{K}$ surpassed those in site groups $\mathrm{J}$ and $F$, respectively. Site group $L$ maintained the lowest height growth rate until about 80 years, but afterward the rate increased and surpassed that in site group $\mathrm{J}$.

Basic statistics for the site-specific height curves and the results of testing against independent data are given in table III. Although some minor biases were found and the average errors were slightly higher than those obtained from the nonindependent tests, the relative errors were comparable for each or all tested groups. Considering that the study stands of Wang et al (1994) were assigned into site groups on the basis of field estimates of SMRs and SNRs, better results from the independent test were not expected.

The conditioned logistic model (eq [2]) was calibrated, and is presented in table IV. 


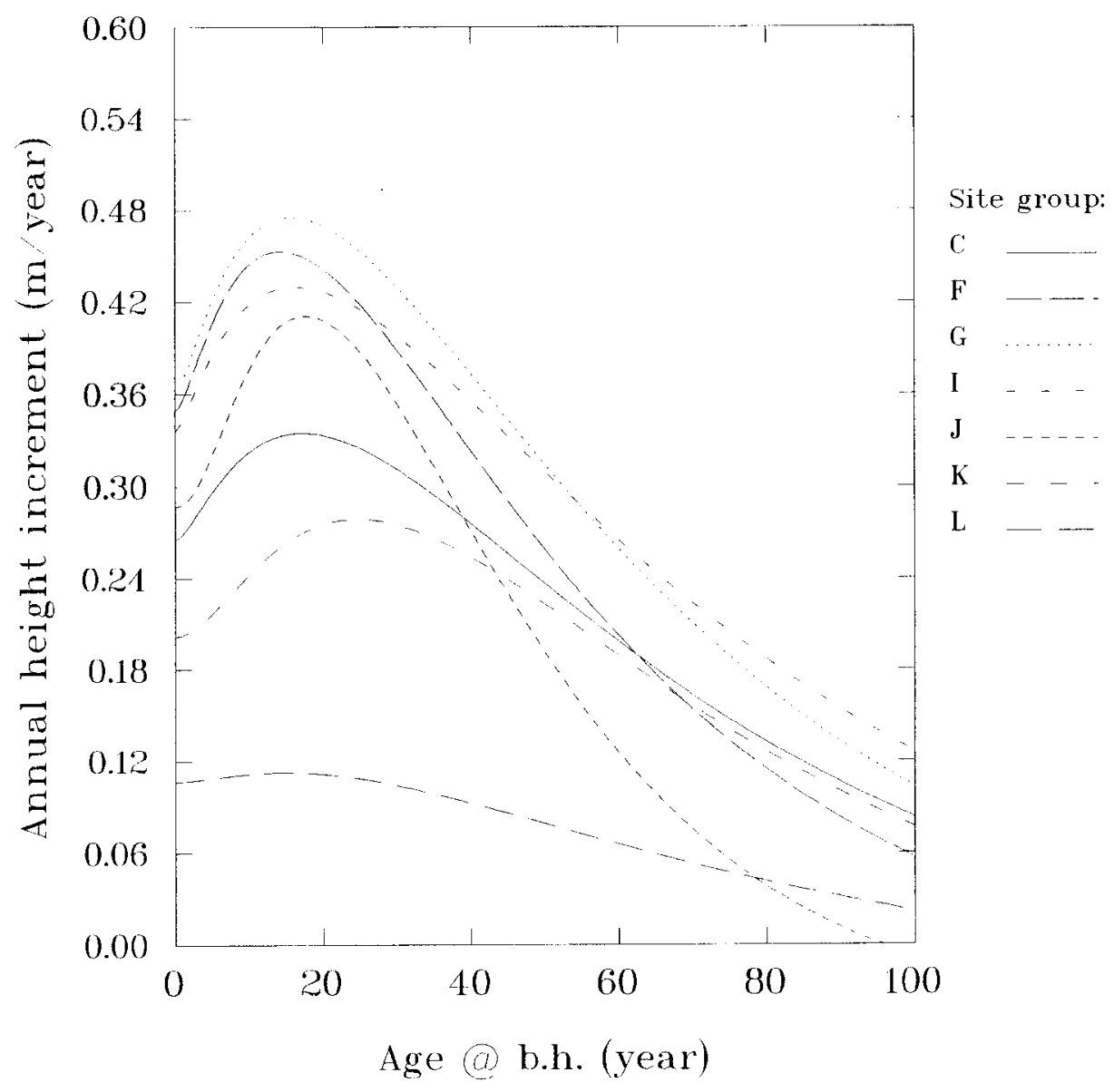

Fig 3. White spruce annual height increment curves for each of the 7 site groups obtained from the differential forms of the site-specific models specified in table II.

Considering all study stands, no significant biases were found in the 2 types of height curves (table V). The precision of the conventional curves was slightly higher than that of site-specific curves in terms of the mean and relative error of height prediction. This was expected as site index was replaced by site group in site-specific models. Site index within any site group was not a point measure, but rather a range measure.
Similar results were also found when prediction precision was compared between the 2 types of height curves for each site group. Except for site group I, the conventional curves were more precise in height prediction than site-specific curves. Although the site-specific height curves yielded a somewhat less precise prediction compared to the conventional height curves, the average error of $0.93 \mathrm{~m}$ and the relative error of 
Table III. Test of site-specific height models for site groups C, F and G using the data of this study and Wang et al (1994).

$\begin{array}{llcccc}\text { Site } & \text { No of } & \text { Residual range } & \text { Mean bias } & \text { Mean error } & \text { Relative error } \\ \text { group } & \text { observations } & (\mathrm{m}) & (\mathrm{m}) & (\mathrm{m}) & (\%)\end{array}$

\begin{tabular}{|c|c|c|c|c|c|}
\hline \multicolumn{6}{|c|}{ Nonindependent test (data of this study) } \\
\hline C & 180 & $-4.11-3.53$ & -0.002 & 1.07 & 8.2 \\
\hline $\mathrm{F}$ & 208 & $-3.04-3.07$ & 0.005 & 0.84 & 5.6 \\
\hline G & 125 & $-3.00-3.12$ & 0.008 & 1.02 & 6.6 \\
\hline Total & 513 & $-4.11-3.53$ & 0.003 & 0.96 & 6.8 \\
\hline \multicolumn{6}{|c|}{ Independent test (data of Wang et al, 1993) } \\
\hline C & 8 & $-3.24-1.30$ & -0.98 & 1.61 & 8. \\
\hline $\mathrm{F}$ & 15 & $-4.43-4.93$ & -0.39 & 1.58 & 6.8 \\
\hline G & 25 & $-4.17-5.06$ & 0.28 & 1.81 & 6.7 \\
\hline Total & 48 & $-4.42-5.06$ & -0.18 & 1.70 & 6.9 \\
\hline
\end{tabular}

Table IV. Coefficients, coefficient of determination and standard error of estimates (SEE) for equation [2] fitted to stem analysis data of this study.

\begin{tabular}{lllll}
$b_{1}$ & $b_{2}$ & $b_{3}$ & $R^{2}$ & $S E E$ \\
\hline 9.565 & -1.451 & -1.263 & 0.987 & 0.84
\end{tabular}

$6.5 \%$ are considered operationally acceptable.

\section{DISCUSSION}

If site classification is based on growth-limiting factors (eg climate, moisture, aeration and nutrients), the resulting classes can be expected to represent sites with similar productivity potentials. Site groups delineated according to these factors made it possible to develop site-specific height curves based on site classification instead of conventional height curves based on site index. Unlike the conventional modelling that expresses height as a function of age and site index, the site-specific modelling used in this study expresses height as a function of age and site groups. The replacement of site index with site group supported the assumption that the effect of site can be adequately represented in growth models without using site index (Wykoff and Monserud, 1987). This gave evidence that site classification provides a useful framework for the study and prediction of forest productivity.

Site-specific curves have several advantages over conventional height curves. First, height at any age could be predicted without using any stand information. This unique feature of site-specific height curves could be very important since they can be used to estimate dominant height of white spruce stands even if a site is occupied by 1) crop stands without suitable site trees, 2) non- 
Table V. Comparisons of the polymorphic height model specified in table IV and the site-specific height models specified in table II.

\begin{tabular}{lccccc}
\hline $\begin{array}{l}\text { Site } \\
\text { group }\end{array}$ & $\begin{array}{c}\text { No of } \\
\text { observations }\end{array}$ & $\begin{array}{c}\text { Residual range } \\
(\mathrm{m})\end{array}$ & $\begin{array}{c}\text { Mean bias } \\
(\mathrm{m})\end{array}$ & $\begin{array}{c}\text { Mean error } \\
(\mathrm{m})\end{array}$ & $\begin{array}{c}\text { Relative } \\
\text { error }(\%)\end{array}$ \\
\hline & & & & & \\
Polymorphic model & & & & \\
C & 150 & $-2.28-3.13$ & 0.006 & 0.64 & 4.7 \\
F & 195 & $-2.18-3.25$ & 0.010 & 0.55 & 3.5 \\
G & 103 & $-1.87-2.32$ & 0.071 & 0.64 & 3.8 \\
I & 17 & $-1.39-1.31$ & 0.151 & 0.82 & 4.4 \\
J & 67 & $-4.10-1.45$ & -0.247 & 0.62 & 4.8 \\
K & 37 & $-2.08-3.29$ & -0.083 & 0.72 & 6.5 \\
L & 27 & $-1.73-0.51$ & 0.148 & 0.43 & 7.4 \\
Total & 596 & $-4.10-3.25$ & -0.004 & 0.61 & 4.1 \\
& & & & & \\
Site-specific & model & & & & \\
C & 180 & $-4.11-3.53$ & -0.002 & 1.07 & 8.2 \\
F & 208 & $-3.04-3.07$ & 0.005 & 0.84 & 5.6 \\
G & 125 & $-3.00-3.12$ & 0.008 & 1.02 & 6.6 \\
I & 27 & $-1.99-1.81$ & -0.006 & 0.74 & 4.6 \\
J & 70 & $-3.08-3.00$ & 0.031 & 0.87 & 6.6 \\
K & 35 & $-2.33-2.14$ & -0.003 & 0.93 & 10.8 \\
L & 27 & $-1.48-1.41$ & -0.002 & 0.71 & 12.2 \\
All & 672 & $-4.11-3.12$ & 0.005 & 0.93 & 6.5 \\
\hline
\end{tabular}

crop stands or 3) nonforest communities. Second, variation in height growth pattern, either due to site index and/or site factors, is implicitly included in the curves. As the height growth pattern of 2 stands with the same site index could be significantly different (eg Carmean, 1956, 1972; Zahner, 1962; Newsberry and Pienaar, 1978; Pfister et al, 1979; Monserud, 1984), this variation may not be accounted for by conventional (polymorphic) height curves that assume that site index determines the height growth pattern of a stand. Third, impact of environmental changes on the future height growth could be accounted for if the effect of these changes on ecological site quality can be predicted.

Given the fact that site productivity is a result of the integrated effects of many environmental factors and given the potential for organizing information and integrating the influences of a large number of interacting variables using models, growth and yield modelling seems to have a useful role within the framework of site classification. However, growth and yield and site classification studies have rarely been coordinated (Crow and Rauscher, 1984), possibly due to lack of joint efforts by biometricians and forest ecologists. The result is a growth model that cannot be easily adapted to a site classification or a site classification that has not been demonstrated to be highly correlated with productivity. To solve this problem, this study linked height modelling with site classification. Unlike previous studies that used both site unit and site index in developing height curves (eg Carmean, 1956; Beck and Trousdell, 1973; Carmean and Kok, 1974; Losch and Schlesinger, 1975; Monserud, 1984), this study used only site unit. 
Many previous studies assumed that height growth pattern varies with site units, and tested this assumption by a graphical comparison of the averaged height curve developed for each site unit (eg Carmean, 1956; Monserud, 1984). This testing, however, may not be necessarily valid. Without knowing within-unit variation, any differences detected among site units may not be substantial. Although this study showed some differences in curve shape among site groups, these differences may or may not reflect the real height growth patterns of the individual stands included in each site group, given the fact that the variation within each site group was not examined. Thus, it could not be proven that site groups were indeed controlling the height growth pattern of white spruce. In fact, a separate study on white spruce height growth pattern indicated that soil moisture, aeration and nutrient regimes are not controlling factors of curve shape (Wang et al, 1994). Even if site groups were not important in determining height growth pattern, their use in height modelling is justified because they are good predictors of white spruce site index (Wang, 1993).

Among 10 subzones of the SBS zone, only 5 subzones (ie dry cool, dry warm, moist cool, moist warm and wet cool) were included in this study. Although no significant differences in white spruce site index were found among the 5 studied subzones (Wang, 1993), the differences in site index between these subzones and the unstudied subzones and among the unstudied subzones themselves, were not examined. As the site-specific models were only tested for the 5 studied subzones, they may not be applicable to other subzones without independent test. Furthermore, the site-specific curves were developed for only 7 of the 13 possible site groups (Wang, 1993); thus, they cannot be applicable to other site groups. However, these 7 site groups may well include all sites that could potentially support productive white spruce growth in the SBS zone.

\section{CONCLUSION}

It appears feasible to develop site-specific height curves without using site index and any other stand attributes as predictors when height modelling is linked to site classification. The site-specific height curves constructed for the 7 broad site units predicted dominant height of the studied white spruce stands with acceptable precision, and the predictions were comparable with the polymorphic height curves. Testing against independent data indicated that these curves could be applied over a large area of the sub-boreal forests of British Columbia.

\section{ACKNOWLEDGMENTS}

The authors thank A Franc for providing a French summary to this paper, and JF Dhote for his helpful review comments on the manuscript.

\section{REFERENCES}

Agren Gl, Axelsson B (1980) PT - a tree growth model. In: Structure and function of northern coniferous forests - an ecosystem study (T Persson, ed), Ecol Bull 32, 525-536

Beck DE, Trousdell DB (1973) Site index: accuracy of prediction. USDA For Serv Res Pap SE-108. Southeastern For Exp Stn, Asheville, NC, USA

Bossel H (1986) Dynamics of forest dieback: systems analysis and simulation. Ecol Modelling 34, 259-228

Bossel $\mathrm{H}$ (1991) Modelling forest dynamics: moving from description to explanation. For Ecol Manage 42, 129 142

Carmean WH (1956) Suggested modifications of the standard Douglas-fir site curves for certain soils in southwestern Washington. For Sci 2, 242-250

Carmean WH (1972) Site index curve for upland oaks in the Central States. For Sci 18, 109-120

Carmean WH, Kok CT (1974) Site quality for Caribbean pine in peninsular Malaysia. Malaysian Forester 37 , 109-119

Clutter JL, Fortson JC, Pienaar LV, Brister GH, Bailey RL (1983) Timber management: a quantitative approach. John Wiley \& Sons, New York, NY, USA 
Crow TR, Rauscher HM (1984) Forest growth model and land classification. In: Forest land classification: experience, problems, perspectives (JG Bockheim, ed), Univ of Wisconsin, Madison, WI, USA

Davis LS, Johnson KN (1987) Forest management, 3rd ed. McGraw-Hill Book Company, New York, NY, USA

Dyer ME, Bailey RL (1987) A test of 6 methods for estimating true heights from stem analysis data. For $\mathrm{Sci}$ $33,3-13$

Goudie JW, Mitchell KJ (1986) The first approximation managed stand yield tables for interior white spruce: initial density. BC Min For, Victoria, BC (unpublished manuscript)

Greene WH (1990) Econometric analysis. Macmillan Publishing Company, New York, NY, USA

Green RN, Marshall PL, Klinka K (1989) Estimating site index of Douglas-fir (Pseudotsuga menziesii [Mirb] Franco) from ecological variables in southwestern British Columbia. For Sci 35, 50-63

Inions G (1990) Classification and evaluation of site in karri (Eucalyptus diversicolor $\mathrm{F}$ Muell) regeneration. I. Edaphic and climatic attributes. For Ecol Manage $32,117-124$

Inions G, Wardell-Johnson G, Annels A (1990) Classification and evaluation of site in karri (Eucalyptus diversicolor $\mathrm{F}$ Muell) regeneration. II. Floristic attributes. For Ecol Manage 32, 125-134

Kimmins JP (1985) Future shock in forest yield forecasting: the need for a new approach. For Chron 61, 503-512

Kimmins JP, Comeau PG, Kurz W (1990) Modelling the interactions between moisture and nutrients in the control of forest growth. For Ecol Manage 30, 361 . 379

Klinka K, Carter RE (1990) Relationships between site index and synoptic environmental factors in immature Douglas-fir stands. For Sci 36, 815-830

Landsberg JJ (1986) Physiological ecology of forest production. Academic Press Inc, London, UK

Leech JW (1984) Modelling for forest management. in: Research for forest management (JJ Landsberg, W Parsons, eds), CSIRO, Melb, 229-232

Losch CK, Schlesinger RC (1975) Predicting site index in young black walnut plantations. USDA For Serv Res Note NC-187, North Central For Exp Stn, St Paul, MN, USA

Meidinger D, Pojar J (1991) Ecosystems of British Columbia. Special Report Series 6, BC Min For, Victoria, $\mathrm{BC}$

Monserud RA (1984) Height growth and site index curves for inland Douglas-fir based on stem analysis data and forest habitat type. For Sci 30, 943-965
Nautiyal JC, Cuoto L (1984) The natural and use of the timber production function: Eucalyptus grandis in Brazil. For Sci 30, 761-773

Newberry JD, Pienaar LV (1978) Dominant height growth models and site index curves for site-prepared slash pine plantations in the lower coastal plain of Georgia and North Florida. Plantation Manage Res Coop Res Paper no 4, Univ of Georgia, Athens, GA, USA

Pfister RD, Kovalchik BL, Arno SF, Presby RC (1979) Forest habitat types of Montana. General Technical Report INT-34, USDA For Serv, Intermountain Forest and Range Experiment Station, Ogden, UT, USA

Pojar J, Klinka K, Meidinger DV (1987) Biogeoclimatic ecosystem classification in British Columbia. For Ecol Manage 22, 119-154

Rayner ME, Turner BJ (1990) Growth and yield modelling of Australia eucalyptus forests. I. Historical development. Australia For 53, 224-237

Richards FJ (1959) A flexible growth function for empirical use. J Exp Bot 10, 290-300

Running SW, Coughlan JC (1988) A general model of forest ecosystem processes for regional application. I. Hydrological balance, canopy gas exchange and primary production processes. Ecol Modelling 42, 125-154

Shugart $\mathrm{HH}$ (1984) Theory of forest dynamics. Springer, New York, NY, USA

Wang GG (1993) Ecological site quality, site index, and height growth of white spruce stands in the subboreal spruce zone of British Columbia. PhD dissertation, Univ of British Columbia, Vancouver, BC

Wang GG, Marshall PL, Klinka K (1994) Height growth pattern of white spruce in relation to site quality. For Ecol Manage 68, 137-147

Wang Q, Wang GG, Coates KD, Klinka K (1994) Use of site factors to product lodgepole pine and interior spruce site index in the sub-boreal spruce zone. Res Note. BC Min For, Victoria, BC, $26 \mathrm{p}$

West PW (1990) Thinning response and growth modelling. In: The young eucalyptus report (CM Kerruish, WHM Rawlins, eds), CSIRO, Melb

Wilkinson L (1990a) SYGRAPH: The system for graphics. SYSTAT Inc, Evanston, IL, USA

Wilkinson $L$ (1990b) SYSTAT: The system for statistics. SYSTAT Inc, Evanston, IL, USA

Wykoff WR, Monserud RA (1987) Presenting site quality in increment models: a comparison of methods. In: Forest growth modelling and prediction, Vol 1, USDA For Serv Gen Tech Rep NC-120. North Central For Exp Stn, Saint Paul, MN, USA, 184-191

Zahner $\mathrm{R}$ (1962) Loblolly pine site curves by soil groups. For Sci 8, 104-110 